\title{
Potensi Penggunaan Eco Enzyme pada Degradasi Deterjen dalam Air Limbah Domestik
}

\author{
Efli Pratamadina $^{1^{*}}$, Temmy Wikaningrum $^{2}$
}

Falkultas Teknik Lingkungan, Universitas Presiden, Bekasi

*Koresponden email: efli.pratamadina@student.president.ac.id

Diterima: 4 Januari 2022

Disetujui: 18 Januari 2022

\begin{abstract}
Environmental pollution is one of the factors causing environmental damage. The environment can accept a certain level of pollutant load and can neutralize it within a certain period. But along with the development of human activities, the amount and level of pollutants are increasing inversely with the capacity of the environment and the ability of the environment to neutralize pollutants. One of the factors causing environmental pollution is domestic wastewater. This research uses orange waste to be processed into the eco enzyme. Making eco enzyme lasts for 3 months. Eco enzyme is made using orange waste, brown sugar, water in a ratio of 3:1:10, and fermentation time is 3 months. This study aims to determine whether the ecoenzyme of orange waste can be used to reduce the concentration of detergent in domestic wastewater. The method used in this research is an experimental method with a laboratory scale. From the experiments carried out, primary data will be obtained. Based on the eco-enzyme characterization of orange waste used, it is known that the concentration of detergent is $0.2534 \mathrm{mg} / \mathrm{L}$. The concentration of detergent in domestic waste is $2.1464 \mathrm{mg} / \mathrm{L}$. The concentration of detergent in domestic waste after added eco-enzyme of orange waste $5 \%$ becomes $0.68 \mathrm{mg} / \mathrm{L}$ and $10 \%$ becomes $0.30 \mathrm{mg} / \mathrm{L}$ with a detention time of 7 days.
\end{abstract}

Keywords: detergent, domestic wastewater, eco enzyme, citrus waste, fruit waste

\begin{abstract}
Abstrak
Pencemaran lingkungan adalah salah satu faktor penyebab rusaknya lingkungan. Lingkungan mampu menerima beban pencemar dalam kadar tertentu dan mampu menetralisirnya dalam rentang waktu tertentu. Tetapi seiring berkembangnya kegiatan manusia, jumlah dan tingkat zat pencemar semakin meningkat berbanding terbalik dengan daya tampung lingkungan dan kemampuan lingkungan dalam menetralisir zat pencemar. Salah satu faktor penyebab pencemaran lingkungan adalah air limbah domestik. Penelitian ini menggunakan sampah jeruk untuk diolah menjadi eco enzyme. Pembuatan eco enzyme berlangsung selama 3 bulan. Eco enzyme dibuat dengan menggunakan sampah jeruk, gula merah, air dengan perbandingan 3 : $1: 10$ dan lama fermentasi 3 bulan. Penelitian ini bertujuan untuk mengetahui apakah eco enzyme sampah jeruk dapat digunakan untuk menurunkan konsentrasi deterjen pada air limbah domestik. Metode yang digunakan dalam penelitian ini adalah metode eksperimen dengan skala laboratorium. Dari eksperimen yang dilakukan akan diperoleh data primer. Berdasarkan karakterisasi eco enzyme sampah jeruk yang digunakan, diketahui konsentrasi deterjen $0,2534 \mathrm{mg} / \mathrm{L}$. Konsentrasi deterjen pada limbah domestik 2,1464 $\mathrm{mg} / \mathrm{L}$. Konsentrasi deterjen pada limbah domestik setelah ditambahkan eco enzyme sampah jeruk 5\% menjadi $0,68 \mathrm{mg} / \mathrm{L}$ dan $10 \%$ menjadi $0,30 \mathrm{mg} / \mathrm{L}$ dengan waktu detensi 7 hari.
\end{abstract}

Kata Kunci : air limbah domestik, deterjen, eco enzyme, sampah jeruk, limbah buah-buahan

\section{Pendahuluan}

Limbah domestik dan sampah organik sering kali diabaikan dalam hal menjadi faktor penyebab kerusakan lingkungan. Jumlah penduduk Indonesia meningkat setiap tahunnya [1]. Pada tahun 2000 penduduk Indonesia berjumlah 206.265.585 jiwa, pada tahun 2010 meningkat menjadi 237.647.326 jiwa. Pada tahun 2020 Indonesia tercatat memiliki 270, 20 juta penduduk. Pertambahan jumlah penduduk akan berbanding lurus dengan bertambahnya kebutuhan air. Bertambahnya kebutuhan air bersih akan berbanding lurus dengan limbah domestik maupun sampah organik yang dihasilkan. Oleh karena itu faktor limbah domestik dalam mencemari lingkungan sangat penting dan tidak bisa diabaikan.

Air limbah domestik adalah air limbah yang bersumber dari kegiatan harian manusia yang berhubungan dengan pemakaian air [2]. Air limbah domestik dihasilkan dari beberapa kegiatan rumah tangga, antara lain : toilet, kamar mandi, wastafel cuci tangan maupun wastafel cuci piring. Air limbah domestik rumah tangga dari perkampungan penduduk cenderung dibuang langsung tanpa dilakukan 
$\overline{\text { pengolahan terlebih dahulu. Hal ini dapat mengakibatkan menurunnya kualitas badan air penerima hingga }}$ kerusakan lingkungan.

Pemerintah telah menetapkan baku mutu air nasional terutama air sungai dengan mengesahkan Peraturan Pemerintah Republik Indonesia No. 22 Tahun 2021 tentang. Penyelenggaraan Perlindungan dan Pengelolaan Lingkungan Hidup lampiran VI tentang Baku Mutu Air Nasional. Pada Peraturan Pemerintah Republik Indonesia No. 22 Tahun 2021 lampiran VI mencantumkan bahwa baku mutu deterjen adalah 0,2 $\mathrm{mg} / \mathrm{L}$ [3]. Baku mutu lingkungan merupakan standar/nilai maksimum konsentrasi pencemar yang bisa ditenggang keberadaannya dalam lingkungan [3] .

Deterjen adalah salah satu bahan pembersih yang terbuat dari campuran bahan-bahan kimia. Deterjen digunakan untuk mencuci pakaian, maupun peralatan rumah tangga dan industri. Tiga komposisi utama deterjen yaitu : surfaktan (zat aktif permukaan), bahan pemutih, dan bahan pengharum [4]. Surfaktan merupakan senyawa organik yang terdiri dari 2 bagian dengan sifat yang berbeda. Surfaktan memiliki bagian yang bersifat hidrofobik (bagian ekor yang menyukai minyak lemak dan tidak menyukai air) dan bagian yang bersifat hidrofilik (bagian kepala yang menyukai air). Surfaktan akan menurunkan tegangan permukaan dan meningkatkan daya serap air, sehingga serat pakaian akan mengendur dan mengangkat noda.

Gugus surfaktan dapat mengalami reaksi hidrolisis yang akan menghasilkan ion fosfat. Ion fosfat ini akan memicu terjadinya eutrofikasi pada badan air penerima. Eutrofikasi akan mengakibatkan tumbuhnya alga dan tanaman air liar. Selain itu deterjen memiliki pH yang sangat basa, bersifat korosif, dan dapat menyebabkan iritasi pada kulit. Surfaktan yang terakumulasi pada badan perairan akan mengakibatkan pendangkalan perairan dan terhambatnya transfer oksigen. Kompleksitas deterjen tergantung pada jenis surfaktan yang digunakan. Semakin panjang rantai kimia surfaktan maka akan semakin sulit untuk terurai.

Eco enzyme merupakan cairan organik kompleks yang dihasilkan dari proses fermentasi bahan organik, gula, dan air [5]. Eco enzyme cenderung berwarna coklat muda dan keruh, tergantung bahan organik yang digunakan sebagai bahan baku fermentasi [6]. Bahan organik yang digunakan untuk pembuatan eco enzyme dapat berupa sampah organik seperti sampah sayuran maupun sampah buah-buahan . Oleh karena itu eco enzyme dapat digunakan sebagai cara pengolahan sampah organik.

Eco enzyme dihasilkan dari proses dekomposisi senyawa karbon yang terdapat pada substrat (sampah jeruk) [7]. Eco enzyme juga dihasilkan dari dekomposisi dari senyawa protein, garam mineral, dan asam organik [8]. Kulit jeruk mengandung bromelain yang dapat menghasilkan enzim amilase. Kulit jeruk juga mengandung asam askorbat yang dapat meningkatkan anti mikroba dan anti inflamasi dari eco enzyme. Asam askorbat yang terdapat pada kulit jeruk yang menyebabkan eco enzyme sampah jeruk memiliki aroma harum segar khas jeruk [9]. Gambar 1 memperlihatkan eco enzyme yang digunakan pada penelitian ini.

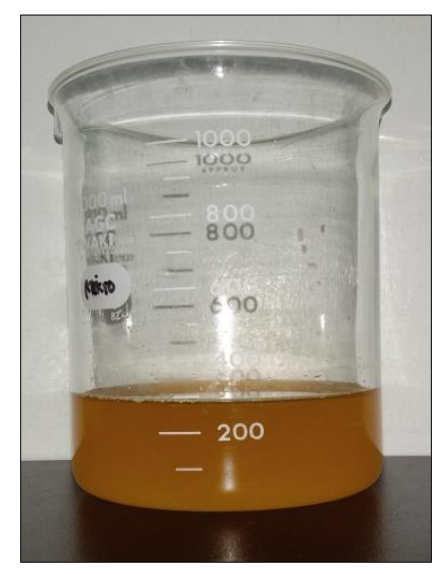

Gambar 1. Eco Enzyme dari sampah jeruk

Sumber : Dokumentasi peneliti, 2021.

Eco enzyme dapat membunuh kuman, bakteri, dan virus karena memiliki kandungan asam asetat dan alkohol. Eco enzyme juga dapat digunakan sebagai pupuk dan menutrisi tanah karena memiliki kandungan nitrit dan residu bahan organik dari proses fermentasi. Eco enzyme mengandung enzim lipase, amilase, dan tripsin. Enzim-enzim tersebut memiliki sifat biokatalisator yang dapat digunakan untuk menurunkan konsentrasi zat pencemar pada air limbah [10]. Penelitian sebelumnya [11] mengenai penurunan konsentrasi polutan menggunakan eco enzyme mampu menurunkan konsentrasi chemical oxygen demand 
(COD) pada limbah domestik. Penelitian ini bertujuan untuk mengetahui apakah eco enzyme sampah jeruk dapat digunakan untuk menurunkan konsentrasi deterjen pada air limbah domestik.

\section{Metode Penelitian}

Data pada penelitian ini adalah data primer yang diperoleh dari hasil pengujian sampel di laboratorium. Metode yang digunakan dalam pengumpulan data adalah metode eksperimen (percobaan) untuk mengetahui pengaruh eco enzyme terhadap penurunan konsentrasi deterjen pada sampel limbah domestik. Data yang diperlukan adalah data konsentrasi awal deterjen pada air limbah. Kemudian data konsentrasi deterjen pada sampel limbah domestik yang ditambahkan eco enzyme dengan waktu detensi 7 hari.

\section{Pembuatan Eco Enzyme}

Berikut ini adalah prosedur pembuatan eco enzyme sampah jeruk :

- Siapkan semua bahan : sampah jeruk (kulit buah/daging buah jeruk), gula aren, dan air bersih.

- Perbandingan bahannya adalah $10: 1: 3$ (air : gula : sampah jeruk).

- Siapkan perlatan yang dibutuhkan. Perlatan yang dibutuhkan adalah wadah berbahan plastik dan bermulut lebar, pisau, dan sendok pengaduk.

- Masukan air bersih dalam wadah.

- Masukan gula aren ke dalam wadah yang berisi air. Aduk (larutkan).

- Kemudian masukan potongan sampah jeruk. Aduk.

- Fermentasi selama 3 bulan.

- Pada bulan pertama buka sebentar tutup wadah seminggu untuk mengeluarkan gas proses fermentasi.

\section{Metode Sampling}

Metode sampling air limbah domestik menggunakan metode SNI 6989.59 Tahun 2008 tentang pengambilan contoh air limbah. Metode ini ditujukan untuk pengambilan air limbah dengan pengujian karakter fisika dan kimia pada air limbah. Contoh uji yang diambil disebut juga contoh sesaat atau random spot sample. Sampel disebut spot sample karena air limbah yang diambil hanya sesaat pada titik lokasi sampling. Populasi sampel disampling secara acak (random sampling). Pengambilan contoh uji menggunakan alat pengambil sederhana, yaitu dengan menggunakan gayung berbahan plastik dan memiliki tangkai panjang. Alat ini juga digunakan untuk pengambilan contoh uji air permukaan, danau, dan air sungai yang relatif dangkal.

Titik pengambilan contoh uji terletak di Desa Jatiwangi Kec. Cikarang Barat dengan titik koordinat $-6^{\circ} 19^{\prime} 21.30 " \mathrm{~S}$ dan $107^{\circ} 5^{\prime} 15.56 " \mathrm{E}$. Titik lokasi pengambilan contoh uji merupakan selokan yang berada di pinggir Jalan Raya Jatiwangi. Lokasi ini dipilih secara sengaja, karena lokasi merupakan daerah padat penduduk. Disepanjang Jalan Raya Jatiwangi terdapat ruko-ruko dan pedagang makanan kaki lima. Selain itu disekitar lokasi terdapat banyak kontrakan yang buangan wastafel/kamar mandinya langsung mengalir ke selokan tersebut. Gambar 2 memperlihatkan titik pengambilan contoh uji atau sampel.

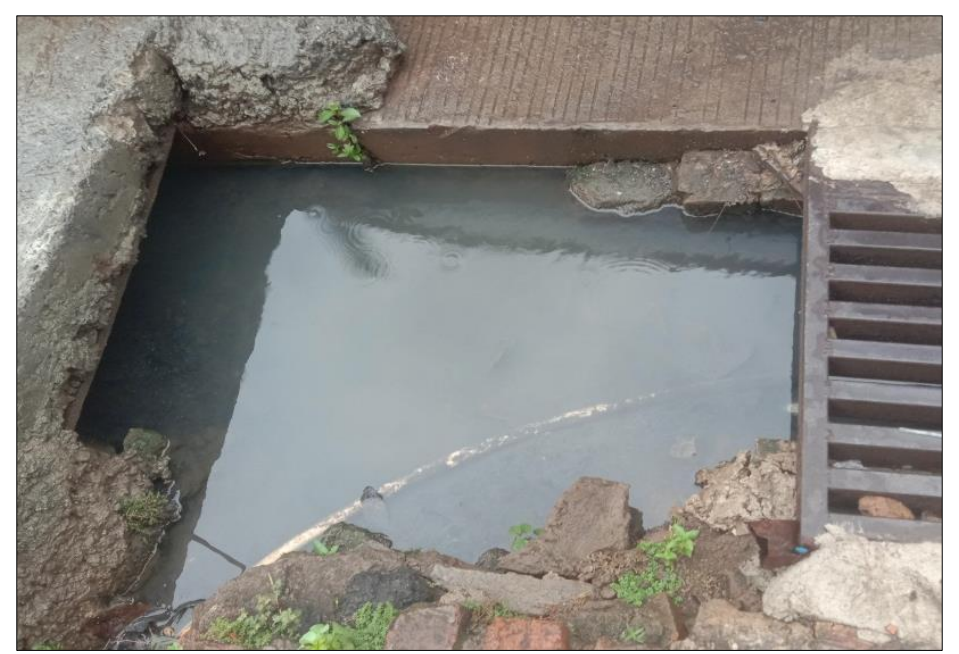

Gambar 2. Titik lokasi sampling

Sumber : Dokumentasi peneliti, 2021 


\section{Pengaplikasian Eco Enzyme Pada Limbah Domestik}

Penelitian ini dilakukan dengan 2 macam perlakuan, yakni dengan penambahan eco enzyme dan tanpa penambahan eco enzyme pada sampel limbah domestik. Berikut ini adalah prosedur pengaplikasian eco enzyme ke dalam limbah domestik :

a. Sampel air limbah domestik yang telah di sampling di homogenisasi.

b. Kemudian air limbah domestik yang sudah homogen dibagi ke dalam beberapa toples/wadah sesuai dengan kebutuhan.

c. Setelah itu, masing-masing toples ditambahkan dengan eco enzyme. Perbandingan eco enzyme dengan air limbah adalah 1:20 dan $2: 20$.

d. Melakukan analisis konsentrasi deterjen pada sampel limbah domestik yang ditambahkan eco enzyme hari ke-0.

e. Melakukan analisis konsentrasi deterjen pada sampel limbah domestik tanpa penambahan eco enzyme hari ke-0.

f. Melakukan analisis konsentrasi deterjen pada sampel setiap 2 hari sekali setelah hari ke-0.

g. Menghitung dan mengambil kesimpulan dari hasil analisis yang dilakukan.

\section{Metode Analisis}

Parameter deterjen dianalisis menggunakan metode SNI 06-6989.51 : 2005 tentang cara pengujian konsentrasi surfaktan anionik dengan menggunakan spektrofotometer dan pereaksi biru metilen. Metode ini digunakan untuk mengukur konsentrasi surfaktan pada air limbah yang direaksikan dengan senyawa biru metilen. Warna yang dihasilkan dari reaksi ini diukur dengan menggunakan spektrofotometer. Hasil pengukuran konsentrasi surfaktan akan sebanding dengan kandungan deterjen pada air limbah. Surfaktan yang bereaksi dengan senyawa biru metilen akan membentuk ion-ion berpasangan dan berwarna biru. Wana biru yang terbentuk dari pasangan ion-ion ini kemudian akan diukur absorbansinya dengan menggunakan spektrofotometer pada panjang $652 \mathrm{~nm}$. Absorbansi yang terukur akan dikonversi menjadi konsentrasi surfaktan $(\mathrm{mg} / \mathrm{L})$. Hasil konsentrasi $(\mathrm{mg} / \mathrm{L})$ yang diperoleh dilaporkan sebagai konsentrasi deterjen pada air limbah domestik.

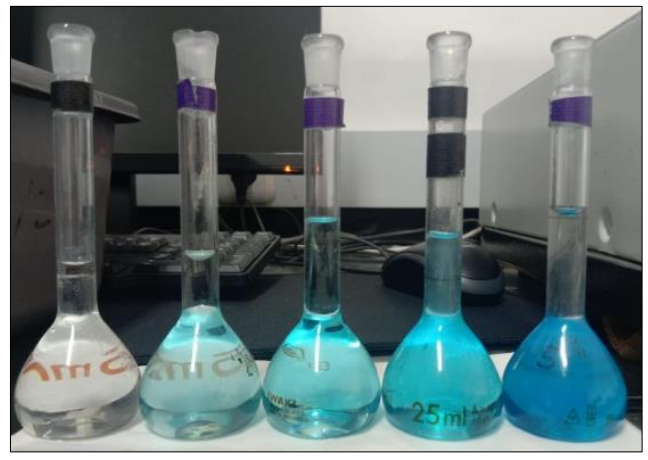

Gambar 3. Deret standar pengujian

Sumber : Dokumentasi penelitian, 2021

Gambar 3 merupakan deret standar yang digunakan pada penelitian. Deret standar berfungsi sebagai acuan dalam penentuan konsentrasi sampel pada penelitian. Semakin tinggi konsentrasi deterjen, maka warna biru yang terbentuk akan semakin pekat dan ini akan berbanding lurus dengan semakin besar nilai absorbansi.

\section{Hasil Dan Pembahasan \\ Hasil Karakterisai Eco Enzyme Sampah Jeruk}

Sebelum melakukan eksperimen, terlebih dahulu dilakukan uji karakterisasi. Tujuan dilakukan uji karakterisasi adalah untuk mengetahui karakterisasi eco enzyme yang akan digunakan, terutama terkait parameter uji yang menjadi variabel terikat dalam penelitian agar tidak terjadi kekeliruan dalam pengolahan data dan pembuatan kesimpulan dari eksperimen yang dilakukan. Tabel 1 adalah hasil uji karakterisasi deterjen pada eco enzyme sampah jeruk yang digunakan. 
Tabel 1. Hasil karakterisasi eco enzyme Eco Enzyme Sampah Jeruk

\begin{tabular}{|c|c|c|c|c|}
\hline \multirow{2}{*}{ No. } & \multirow{2}{*}{ Parameter } & \multicolumn{3}{|c|}{ Hasil (mg/L) } \\
\hline & & Simplo & Duplo & Rata-rata \\
\hline 1. & Deterjen & 0,2504 & 0,2564 & 0,2534 \\
\hline
\end{tabular}

Dari pengujian karakterisasi yang dilakukan, diketahui bahwa pada eco enzyme sampah jeruk terdapat $0,2534 \mathrm{mg} / \mathrm{L}$ deterjen. Selanjutnya dilakukan uji karakterisasi deterjen pada sampel limbah domestik. Uji karakterisasi ini bertujuan untuk mengetahui konsentrasi mula-mula deterjen pada sampel limbah domestik. Tabel 2 merupakan hasil uji karakterisasi deterjen pada limbah domestik yang digunakan

Tabel 2. Hasil karakterisasi limbah domestik

\begin{tabular}{|c|c|c|c|c|}
\hline \multicolumn{5}{|c|}{ Karakterisasi Limbah Domestik } \\
\hline \multirow{2}{*}{ No. } & \multirow{2}{*}{ Parameter } & \multicolumn{3}{|c|}{ Hasil (mg/L) } \\
\hline & & Simplo & Duplo & Rata-rata \\
\hline 1. & Deterjen & 2,1447 & 2,1481 & 2,1464 \\
\hline
\end{tabular}

Dari uji karakterisasi deterjen pada limbah sampel limbah domestik diketahui bahwa konsentrasi rata-rata deterjen pada limbah domestik adalah 2,1464 mg/L. Hal ini memperjelas bahwa pada sampel limbah domestik terdapat deterjen sebagai salah satu polutan. Oleh karena itu sampel limbah domestik dapat digunakan sebagai sampel pada eksperimen ini. Selanjutnya dilakukan penelitian dan pengamatan terhadap sampel limbah domestik yang di tambahkan eco enzyme sampah jeruk dan sampel limbah domestik tanpa penambahan eco enzyme. Berdasarkan penelitian yang dilakukan, didapatkan hasil pada Tabel 3 dan Tabel 4.

Tabel 3. Hasil penelitian dengan penambahan eco enzyme 5\%

\begin{tabular}{|c|c|c|c|c|c|c|c|}
\hline \multirow[t]{2}{*}{ No. } & \multirow[t]{2}{*}{ Hari } & \multicolumn{3}{|c|}{$\begin{array}{l}\text { Sampel Tanpa Eco Enzyme } \\
(\mathrm{mg} / \mathrm{L})\end{array}$} & \multicolumn{3}{|c|}{ Sample + Eco Enzyme (mg/L) } \\
\hline & & Simplo & Duplo & Rata-rata & Simplo & Duplo & Rata-rata \\
\hline 1. & 0 & 1,9391 & 1,9380 & 1,9385 & 1,9276 & 1,9287 & 1,9281 \\
\hline 2. & 2 & 0,8466 & 0,8841 & 0,8653 & 0,6262 & 0,6251 & 0,6256 \\
\hline 3. & 4 & 0,8499 & 0,8485 & 0,8492 & 0,6784 & 0,6770 & 0,6777 \\
\hline 4. & 7 & 0,8495 & 0,8460 & 0,8477 & 0,6791 & 0,6802 & 0,6796 \\
\hline
\end{tabular}

Sumber : Data penelitian, 2021.

Tabel 4. Hasil penelitian dengan penambahan eco enzyme $10 \%$

\begin{tabular}{lccccccc}
\hline \multicolumn{7}{c}{ Nengan Penambahan Eco Enzyme 10\% } \\
\hline \multirow{2}{*}{ No. } & Hari & \multicolumn{3}{c}{$\begin{array}{c}\text { Sampel Tanpa Eco Enzyme } \\
\text { (mg/L) }\end{array}$} & & \multicolumn{3}{c}{ Sampel + Eco Enzyme (mg/L) } \\
\cline { 3 - 8 } & & Simplo & Duplo & Rata-rata & Simplo & Duplo & Rata-rata \\
\hline 1. & 0 & 1,9391 & 1,9380 & 1,9385 & 1,9210 & 1,9216 & 1,9213 \\
2. & 2 & 0,8466 & 0,8841 & 0,8653 & 0,3206 & 0,3285 & 0,3245 \\
3. & 4 & 0,8499 & 0,8485 & 0,8492 & 0,3034 & 0,3048 & 0,3041 \\
4. & 7 & 0,8495 & 0,8460 & 0,8477 & 0,3016 & 0,3023 & 0,3019 \\
\hline
\end{tabular}

Sumber : Data penelitian, 2021.

Berdasarkan data primer yang diperoleh dapat dilihat bahwa sampel limbah domestik dengan penambahan eco enzyme memiliki konsentrasi akhir yang lebih kecil dibandingkan dengan sampel limbah domestik tanpa penambahan eco enzyme. Baik dengan penambahan 5\% eco enzyme, maupun dengan penambahan $10 \%$ eco enzyme. Hal ini menunjukkan bahwa eco enzyme dapat membantu proses degradasi deterjen pada sampel air limbah domestik.

Eco enzyme mengandung enzim amilase, tripsin, dan lipase. Enzim lipase memiliki sifat biokatalisator yang dapat membantu proses degradasi surfaktan dalam deterjen. Berdasarkan hasil penelitian pendahulu diketahui bahwa enzyme lipase mampu mempercepat laju reaksi degradasi [12]. Proses degradasi deterjen diawali dengan reaksi oksidasi pada gugus alkil, proses ini membutuhkan koenzim. Proses ini menyebabkan rantai alkil mengalami pemendekan, reaksi ini berlangsung hingga 
menyisakan 4-5 atom karbon pada rantai alkil. Setelah rantai alkil menjadi pendek, maka akan terjadi proses desulfonasi. Desulfonasi adalah proses yang mengakibatkan hilangnya gugus sulfonat yang dikatalis dengan enzim, koenzim, dan oksigen [4].

\section{Kesimpulan}

Berdasarkan data hasil penelitian diketahui bahwa konsentrasi mula-mula deterjen pada limbah domestik tanpa penambahan eco enzyme adalah $1,9385 \mathrm{mg} / \mathrm{L}$, kemudian turun menjadi $0,8477 \mathrm{mg} / \mathrm{L}$ pada hari ke-7. Sampel limbah domestik dengan penambahan eco enzyme $5 \%$ turun menjadi $0,6796 \mathrm{mg} / \mathrm{L}$ dan penambahan $10 \%$ eco enzyme turun menjadi $0,3019 \mathrm{mg} / \mathrm{L}$ pada hari ke-7. Sehingga dapat diketahui bahwa sampel limbah domestik dengan penambahan eco enzyme memiliki konsentrasi akhir yang lebih rendah dibandingkan sampel limbah domestik tanpa penambahan eco enzyme. Hal ini membuktikan bahwa eco enzyme dapat membantu proses degradasi deterjen pada air limbah domestik.

\section{Ucapan Terima Kasih}

Penulis mengucapkan terima kasih kepada para dosen di Universitas Presiden yang telah memberikan wawasan dan keahlian yang sangat membantu dalam menyelesaikan penelitian ini.

\section{Referensi}

[1] S. Rossi Prabowo, Aziz Nur Bambang, "Population Growth And Agricultural Land Conversion," Semarang, 2020.

[2] K. Rya, "Peraturan Menteri Lingkungan Hidup Dan Kehutanan Republik Indonesia No. P.68," 2016.

[3] Pemerintah Republik Indonesia, "Peraturan Pemerintah Republik Indonesia Nomor 22 Tahun 2021 Tentang Penyelenggaraan Perlindungan dan Pengelolaan Lingkungan Hidup," Sekr. Negara Republik Indones., vol. 1, no. 078487A, p. 483, 2021.

[4] M. A. Kamaruddin, M. H. Ibrahim, L. M. Thung, M. I. Emmanuel, N. M. Niza, A. M. H. Shadi. F. A. Norashiddin, "Sustainable synthesis of pectinolytic enzymes from citrus and Musa acuminata peels for biochemical oxygen demand and grease removal by batch protocol," Appl. Water Sci., vol. 9, no. 4, pp. 1-10, 2019, doi: 10.1007/s13201-019-0948-2.

[5] C. Wen Low, R. Leong Zhi Ling, and S.-S. Teo, "Effective Microorganisms in Producing EcoEnzyme from Food Waste for Wastewater Treatment," Appl. Microbiol. Theory \& Technol., pp. 2836, 2021, doi: 10.37256/amtt.212021726.

[6] N.- Rochyani, R. L. Utpalasari, and I. Dahliana, "Analisis Hasil Konversi Eco Enzyme Menggunakan Nenas (Ananas comosus ) Dan Pepaya (Carica papaya L.)," J. Redoks, vol. 5, no. 2, p. 135, 2020, doi: 10.31851/redoks.v5i2.5060.

[7] V. C. Renge, S. V Khedkar, and N. R. Nandurkar, "Enzyme Synthesis By Fermentation Method : A Review," Chem. Commun, vol. 2, no. 4, pp. 585-590, 2012, [Online]. Available: www.sadgurupublications.com.

[8] C. Arun and P. Sivashanmugam, "Investigation of biocatalytic potential of garbage enzyme and its influence on stabilization of industrial waste activated sludge," Process Saf. Environ. Prot., vol. 94, no. C, pp. 471-478, 2015, doi: 10.1016/j.psep.2014.10.008.

[9] Imelda, D., Satriawan, B. D., \& Alif, A. B, "Pembuatan Produk Multipurpose Cleaner Dengan Pemanfaatan Eco Enzyme Dari Limbah Kulit Buah Sebagai Bahan Aktif Natural Antimikroba," Laporan akhir penelitian, 2021.

[10] Z. Wang, X. Yu, J. Li, J. Wang, and L. Zhang, "The use of biobased surfactant obtained by enzymatic syntheses forwax deposition inhibition and drag reduction in crude oil pipelines," Catalysts, vol. 6, no. 5, May 2016, doi: 10.3390/catal6050061.

[11] Bharvi S. Patel, Bhanu R. Solanki, and Archana U. Mankad, "Effect of eco-enzymes prepared from selected organic waste on domestic waste water treatment," World J. Adv. Res. Rev., vol. 10, no. 1, pp. 323-333, Apr. 2021, doi: 10.30574/wjarr.2021.10.1.0159.

[12] C. Arun and P. Sivashanmugam, "Solubilisation Of Waste Activated Sludge Using Garbage Enzyme Produced From Different Pre-Consumer Organic Waste," RSC advances 5, 2015, no. 63 (2015): 51421-51427.

[13] C. Arun and P. Sivashanmugam, "Study on optimization of process parameters for enhancing the multi-hydrolytic enzyme activity in garbage enzyme produced from preconsumer organic waste," Bioresour. Technol., vol. 226, pp. 200-210, 2017, doi: 10.1016/j.biortech.2016.12.029.

[14] Yusriani Sapta Dewi, "Efektivitas Degradasi Surfaktan Dengan Bakteri Pseudomonas putida," J. Ilm. Univ. Satya Negara Indones. 2012. 
[15] M. Fajaruddin Natsir, A. Anggi Liani, and A. Dwi Fahsa, "Analisis Kualitas Bod, Cod, Dan Tss limbah Cair Domestik (Grey Water) Pada Rumah Tangga Di Kabupaten Maros," Jurnal Nasional Ilmu Kesehatan. 2021.

[16] Made Rai Rahayu, M. Nengah, and Yohanes Parlindungan Situmeang, "Acceleration of Production Natural Disinfectants from the Combination of Eco-Enzyme Domestic Organic Waste and Frangipani Flowers (Plumeria alba)," SEAS (Sustainable Environ. Agric. Sci., vol. 5, no. 1, pp. 15-21, Apr. 2021, doi: 10.22225/seas.5.1.3165.15-21.

[17] S. I. Megah, D. S. Dewi, and E. Wilany, "Pemanfaatan Limbah Rumah Tangga Digunakan Untuk Obat Dan Kebersihan," Minda Baharu, vol. 2, no. 1, p. 50, Jul. 2018, doi: 10.33373/jmb.v2i1.2275.

[18] F. Nazim, "Treatment of Synthetic Greywater Using 5\% and 10\% Garbage Enzyme Solution," Bonfring Int. J. Ind. Eng. Manag. Sci., vol. 3, no. 4, pp. 111-117, 2013, doi: 10.9756/bijiems.4733.

[19] M. Hemalatha and P. Visantini, "Potential use of eco-enzyme for the treatment of metal based effluent," in IOP Conference Series: Materials Science and Engineering, Feb. 2020, vol. 716, no. 1, doi: 10.1088/1757-899X/716/1/012016.

[20] M. Janarthanan, K. Mani, and S. R. S. Raja, "Purification of Contaminated Water Using Eco Enzyme," IOP Conf. Ser. Mater. Sci. Eng., vol. 955, no. 1, 2020, doi: 10.1088/1757-899X/955/1/012098. 